\title{
Application Frequency Research on Insomnia Correlated Treatment of Chinese Herbs
}

\author{
Yuan Sheng Liao, Wei Wu Cai, Rui Ling Yang, Li Li Gao and Cheng Han Wu* \\ Department of Neurology, Clinical College of Fujian University of Traditional Chinese Medicine, Fuzhou, China
}

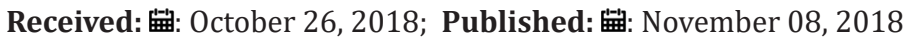

*Corresponding author: Cheng Han Wu, Department of Neurology, Clinical College of Fujian University of Traditional Chinese Medicine, Fuzhou, China

\section{Abstract}

Objective: To study common Chinese herbs related to treatment of insomnia and their efficacy classification, providing references for their applications in treating insomnia.

Methods: By using information quantitative statistics method, 8176778 literatures in CNKI China Academic Journal Network Publishing Database (CAJD), Medical and Health Science and Technology Database were retrieved from 1996 to 2016.Full-text retrieval was performed by taking insomnia as "key word". Totally 500 commonly used herbs with higher application frequency were retrieved as "key word"twice. Their application frequencies were statistically calculated. Then they were classified and analyzed by effectiveness in Chinese Materia Medica according to statistical results.

Results: Herbs for insomnia related treatment with higher application frequency were sequenced from high to low as licorice root(56183 times), Chinese Angelica(54817), Astragalus Atractylodes(45964), Salvia Miltiorrhiza(45959), Radix Bupleuri(44034), Radix Paeoniae alba(39525), Astragalus membranaceus(39370), Tuckahoe(37319), pinellia(36268), Dangshen(35292), and so on.Recipes consisted of them were Suanzao Ren Decoction, Jiaotai Pill, Guipi Decoction and so on. According to effectiveness in Chinese Materia Medica, Chinese herbs with higher application frequency after comprehensive analysis were deficiency supplementing herbs, heat clearing herbs, activating blood circulation and removing blood stasis herbs qi regulating herbs, sedative herbs, and so on.

Conclusion: Deficiency supplementing herbs, heat clearing herbs, activating blood circulation and removing blood stasis herbs,qi regulating herbs, sedative herbs were commonly used Chinese herbs for treatment of insomnia.

Keywords: Insomnia; Chinese Herbal Treatment; Correlation; Information Quantitative Statistics

\section{Introduction}

Insomnia is the most common sleep disorder, is a very common complaint of patients in various clinical departments, belongs to the category of "insomnia" in traditional Chinese medicine, Huangdi's Classic known as "insomnia", "cannot sleep", "cannot lie down", for a variety of reasons lead to insomnia caused by distracted sleep disorders. Chinese medicine is currently one of the most commonly used methods to treat the disease [1-3]. In order to objectively evaluate the commonly used Chinese medicines and their categories in the treatment of insomnia, this study used quantitative statistics to analyze the frequency of modern application of Chinese medicines related to insomnia and classified them according to the efficacy of Chinese Materia Medica. The results are reported below.

\section{Data and Methods}

\section{Data Source}

With insomnia and 500 kinds of commonly used Chinese medicines as keywords, 8176778 articles were accurately retrieved from China How Net, China Academic Journal Network Publishing
General Library and Medical and Health Science and Technology Database from 1996 to 2016. The retrieval methods are as follows: firstly, insomnia is used as the search term, and then 500 kinds of commonly used Chinese medicines are used as the search term for the second time. At the same time, the documents detected in the two searches are analyzed according to the following criteria, and the number of articles that meet the inclusion criteria are recorded, counted and sorted respectively.

\section{Literature Inclusion and Exclusion Criteria}

Inclusion criteria: literature on clinical (clinical research, clinical trials, clinical observations, clinical reports, clinical experience, etc.) and experimental (pharmacodynamic experiments, pharmacokinetic experiments, etc.); exclusion criteria: items, indexes and review of analytical literature.

\section{Statistical Ranking Method}

The number of articles in each Chinese medicine which were retrieved twice and met the inclusion criteria was recorded before 
the name of the Chinese medicine (one paragraph for each drug name, the number of articles recorded was based on 5 digits, and those Less than 5 digits make up 5 figures with 0 before figures), such as "06710 magnet". Automatic ranking of paragraphs according to numbers in Word documents.

\section{Classification Study}

After searching, 500 kinds of traditional Chinese medicines were arranged in descending order. Only the first 200 kinds were classified according to the efficacy of Chinese Materia Medica. The total frequency and average frequency of the first and second classifications were listed respectively.

\section{Result}

Frequency of application of Chinese medicines for insomnia (Table 1). The first 50 medicines included Suanzaoren Decoction (Suanzaoren, Ligusticum chuanxiong, Anemarrhenae, Poria cocos, Licorice), Guipi Decoction (Atractylodes macrocephala, Ginseng, Astragalus, Angelica sinensis, Licorice, Fuling, Polygala, Suanzaoren, Muxiang, Longan, Ginger, Dazao), Jiaotai pill (Coptis chinensis, Cinnamomum cassia) Commonly used prescriptions for insomnia.

Table 1: Table of application frequency of insomnia related Chinese Medicine.

\begin{tabular}{|c|c|c|c|c|}
\hline Name/Frequency & Name/Frequency & Name/Frequency & Name/Frequency & Name/Frequency \\
\hline Licorice 56183 & Ligustrum lucidum 17190 & Malt 09785 & Leech 05952 & Glehnia Littoralis 04036 \\
\hline Chinses Angelica & Gardenia 17172 & $\begin{array}{c}\text { Mother-of-pearl } \\
09776\end{array}$ & $\begin{array}{c}\text { Cistanche } \\
\text { Cistanche } 05862\end{array}$ & $\begin{array}{c}\text { Glauber's salt } \\
04026 \\
\end{array}$ \\
\hline Atractylodes 45964 & $\begin{array}{c}\text { Chrysanthemum } \\
16351\end{array}$ & $\begin{array}{c}\text { Sophora flavescens } \\
09755\end{array}$ & Papaya 05850 & $\begin{array}{c}\text { Semen Raphani } \\
04008\end{array}$ \\
\hline Miltiorrhiza 45959 & Costusroot 16328 & Psoralen 09681 & $\begin{array}{c}\text { Polygonum } \\
\text { cuspidatum } 05745\end{array}$ & Radix Isatidis 03885 \\
\hline Bupleurum root 44034 & $\begin{array}{c}\text { Rhynchophylla } \\
16136 \\
\end{array}$ & Cohosh 9464 & Cinnabar 05653 & $\begin{array}{c}\text { Prunella Vulgaris } \\
03880\end{array}$ \\
\hline $\begin{array}{c}\text { Paeonia lactiflora } \\
39525 \\
\end{array}$ & Eucommia 15804 & $\begin{array}{c}\text { Trichosanthes } \\
09464\end{array}$ & Angelica 05618 & Hempseed 03804 \\
\hline Astragalus membranaceus 39370 & $\begin{array}{c}\text { Magnolia officinalis } \\
15634\end{array}$ & Coix seed 09135 & Borneol 05388 & Gorgon fruit 03792 \\
\hline Poria cocos 37319 & $\begin{array}{c}\text { Panax notoginseng } \\
15630 \\
\end{array}$ & $\begin{array}{l}\text { Bombyx } \\
\text { Batryticatus } 09118\end{array}$ & $\begin{array}{c}\text { Soviet wood } \\
05244 \\
\end{array}$ & $\begin{array}{c}\text { Rhizoma Smilacis } \\
\text { Glabrae } 03727\end{array}$ \\
\hline $\begin{array}{c}\text { Pinelliaternata } \\
36268\end{array}$ & Figwort 15581 & Honeysuckle 08928 & $\begin{array}{l}\text { Fructus Tritici } \\
\text { Levis } 05235\end{array}$ & Reddle 03660 \\
\hline $\begin{array}{c}\text { Codonopsis } \\
\text { pilosula } 35292\end{array}$ & $\begin{array}{l}\text { Radix rehmanniae } \\
\text { Rehmanniae } 15331\end{array}$ & Radix Gentianae 08910 & $\begin{array}{c}\text { Mustard seed } \\
05190\end{array}$ & $\begin{array}{c}\text { Perilla frutescens } \\
\text { crispa } 03638\end{array}$ \\
\hline $\begin{array}{c}\text { Dried tangerine } \\
\text { peel } 31533 \\
\end{array}$ & Atractylodes lancea 15221 & Rhizoma sparganii 08874 & Pangolin 05182 & Pilose antler 03551 \\
\hline $\begin{array}{c}\text { Coptis chinensis } \\
31394 \\
\end{array}$ & Donkey-hide gelatin 15151 & $\begin{array}{c}\text { Herba Epimedii } \\
08857\end{array}$ & Cassia seed 05181 & Perillaseed 03478 \\
\hline $\begin{array}{l}\text { Fingered citron } \\
28970 \\
\end{array}$ & $\begin{array}{l}\text { Lilium brownii } \\
15107\end{array}$ & $\begin{array}{c}\text { Morinda officinalis } \\
08777 \\
\end{array}$ & $\begin{array}{l}\text { Excrementum } \\
\text { pteropi } 05175\end{array}$ & Musk 03473 \\
\hline Flos Carthami 28490 & $\begin{array}{l}\text { The fruit of Chinese wolfberry } \\
\qquad 14460\end{array}$ & Oriental wormwood 08633 & $\begin{array}{l}\text { American ginseng } \\
05156\end{array}$ & Fructus viticis 03402 \\
\hline Ligusticum wallichii 28416 & $\begin{array}{c}\text { Fructus amomi } \\
13674 \\
\end{array}$ & Scorpio 08532 & $\begin{array}{c}\text { Mulberry leaves } \\
05144 \\
\end{array}$ & $\begin{array}{c}\text { Round cardamom } \\
03387 \\
\end{array}$ \\
\hline Yam 28072 & $\begin{array}{c}\text { Radix } \\
\text { Pseudostellariae } 13380\end{array}$ & $\begin{array}{l}\text { Concha haliotidis } \\
08009\end{array}$ & $\begin{array}{l}\text { Herbapatchoui } \\
05137\end{array}$ & $\begin{array}{c}\text { Cannon ginger } \\
03212 \\
\end{array}$ \\
\hline $\begin{array}{c}\text { Radix } \\
\text { Ophiopogonis } \\
27945\end{array}$ & Dried ginger 13371 & Plaster 07887 & $\begin{array}{c}\text { Rhizoma } \\
\text { imperatae } 04990\end{array}$ & Lulu Tong 03200 \\
\hline
\end{tabular}




\begin{tabular}{|c|c|c|c|c|}
\hline Ginseng 27844 & Pberetima 13155 & $\begin{array}{c}\text { Endothelium } \\
\text { Corneum gigeriae } \\
\text { galli } 07834\end{array}$ & Mulberry bark 04989 & Cockroach 03184 \\
\hline $\begin{array}{c}\text { Peach kernel } \\
26869\end{array}$ & $\begin{array}{c}\text { Cortex Moutan } \\
12238\end{array}$ & $\begin{array}{c}\text { Semen nelumbinis } \\
07792\end{array}$ & Centipede 04967 & Fructus rubi 03170 \\
\hline $\begin{array}{l}\text { Radix Paeoniae } \\
\text { Paeoniae } 26696\end{array}$ & $\begin{array}{l}\text { lignum millettiae } \\
12061\end{array}$ & Turtle shell 07790 & $\begin{array}{c}\text { Fritillaria } \\
\text { thunbergii } 04883\end{array}$ & $\begin{array}{c}\text { Tripterygium } \\
\text { wilfordii } 03166\end{array}$ \\
\hline $\begin{array}{l}\text { Semen zizyphi } \\
\text { spinosae } 25914\end{array}$ & $\begin{array}{c}\text { Ephdra sinica Stapf } \\
12004\end{array}$ & $\begin{array}{c}\text { Cortex lycii radicis } \\
07756\end{array}$ & $\begin{array}{c}\text { Hairyvein } \\
\text { agrimony } 04863\end{array}$ & Monkshood 03131 \\
\hline Tulip 25794 & $\begin{array}{l}\text { Bambusae caulis im taeniam } \\
11870\end{array}$ & Pericarp 07473 & Talc 04826 & $\begin{array}{c}\text { Ramulus mori } \\
03121\end{array}$ \\
\hline $\begin{array}{c}\text { Schisandra } \\
\text { chinensis } 25331\end{array}$ & $\begin{array}{c}\text { Platycodon } \\
\text { grandiflorum } 11749\end{array}$ & Cassia twig 07349 & Bezoar 04688 & Inula 03108 \\
\hline $\begin{array}{l}\text { Radix achyranthis } \\
\text { bidentatae } 24023\end{array}$ & $\begin{array}{l}\text { Fructus aurantii Immaturus } \\
11725\end{array}$ & Medicated leaven 07318 & Alizara 04668 & Fructus Cnidium 03028 \\
\hline Rheum officinale 23594 & Semen corni 11715 & $\begin{array}{c}\text { Herba Hedyotis } \\
07300\end{array}$ & $\begin{array}{c}\text { Radix clematidis } \\
04637\end{array}$ & $\begin{array}{c}\text { Rhizoma cibotii } \\
02992\end{array}$ \\
\hline $\begin{array}{c}\text { Rhizoma alismatis } \\
22142 \\
\end{array}$ & $\begin{array}{c}\text { Yellow semen } \\
11672 \\
\end{array}$ & $\begin{array}{c}\text { Curcuma zedoary } \\
07084\end{array}$ & $\begin{array}{c}\text { Herba eupatorii } \\
04634\end{array}$ & Kelp 02970 \\
\hline Monkshood 21884 & Motherwort 11607 & Myrrh 06718 & $\begin{array}{l}\text { Houttuynia cordata } \\
04580\end{array}$ & $\begin{array}{c}\text { Fructus rosae } \\
\text { laevigatae } 02962\end{array}$ \\
\hline $\begin{array}{l}\text { Polygala root } \\
21780\end{array}$ & Forsythia suspense 11519 & Magnetite 06710 & $\begin{array}{c}\text { Sanguisorba } \\
\text { officinalis } 04574\end{array}$ & Testa mungo 02961 \\
\hline $\begin{array}{c}\text { Baikal Skullcap } \\
21584\end{array}$ & $\begin{array}{c}\text { Acorus calamus } \\
11517\end{array}$ & Pollen cattail 06672 & Grifola 04548 & Arteannuin 02957 \\
\hline $\begin{array}{c}\text { Rhizoma Cyperi } \\
21481\end{array}$ & $\begin{array}{c}\text { Polygonum } \\
\text { multiflorum } 11330\end{array}$ & $\begin{array}{c}\text { Fructus meliae } \\
\text { toosendan } 06669\end{array}$ & $\begin{array}{c}\text { Cicada slough } \\
04547\end{array}$ & $\begin{array}{c}\text { Cortex dictam } \\
02915\end{array}$ \\
\hline $\begin{array}{c}\text { Anemarrhena } \\
21105\end{array}$ & $\begin{array}{c}\text { Cortex albizziae } \\
11035\end{array}$ & Asparagus 06618 & Seaweed 04514 & $\begin{array}{l}\text { Fructus kochiae } \\
02881\end{array}$ \\
\hline $\begin{array}{l}\text { Fossil fragments } \\
19317 \\
\end{array}$ & $\begin{array}{c}\text { Semen boitae } \\
10989 \\
\end{array}$ & $\begin{array}{c}\text { Frankincense } \\
06597\end{array}$ & Honey 04497 & Eclipta 02738 \\
\hline $\begin{array}{c}\text { Phellodendron } \\
18948\end{array}$ & $\begin{array}{c}\text { Plantago seed } \\
10863 \\
\end{array}$ & $\begin{array}{c}\text { Jade bamboo } \\
06519\end{array}$ & $\begin{array}{c}\text { Radix lithospermi } \\
04449 \\
\end{array}$ & Cornu bubali 02737 \\
\hline $\begin{array}{l}\text { Fructus Ziziphi } \\
\text { Jujubae } 18907\end{array}$ & Corydalis ambigua Ch. 10672 & $\begin{array}{c}\text { Radix dipsaci } \\
06471 \\
\end{array}$ & $\begin{array}{l}\text { Allii macrostemi } \\
\text { bulbus } 04402\end{array}$ & $\begin{array}{c}\text { Dragon's blood } \\
02729 \\
\end{array}$ \\
\hline Ginger 18505 & Dodder 10425 & Dark plum 06423 & Aloes 04336 & Cornu antelopis 02720 \\
\hline Cinnamon 18299 & $\begin{array}{c}\text { Parasitic loranthus } \\
10404 \\
\end{array}$ & Dendrobium 06340 & Amber 04231 & $\begin{array}{c}\text { Angelica decursiva } \\
02657\end{array}$ \\
\hline $\begin{array}{c}\text { Pueraria lobata } \\
17847\end{array}$ & Hawthorn 10212 & Evodia 06277 & Clove 04217 & Desmodium 02639 \\
\hline Oysters 17435 & Mint 10206 & Higenamine 06266 & Artemisia 04084 & $\begin{array}{c}\text { Cordyceps sinensis } \\
02614\end{array}$ \\
\hline $\begin{array}{c}\text { Rehmannia } \\
\text { glutinosa } 17273\end{array}$ & $\begin{array}{l}\text { Semen amomi } \\
\text { amari } 10200\end{array}$ & Turmeric 06080 & $\begin{array}{c}\text { Placenta Hominis } \\
04084\end{array}$ & $\begin{array}{c}\text { Bletilla striata } \\
02609\end{array}$ \\
\hline Gastrodin 17195 & Dandelion 09848 & Lentil 06068 & Patrinia 04054 & Tabaschir 02537 \\
\hline
\end{tabular}


The top 200 kinds of Chinese medicine related to insomnia were classified according to the results of Chinese Materia Medica (Table 2). According to the first-class efficacy classification, the top five frequencies were Tonic medicines (623628), Antipyretic (295220), Huoxue Huayu (271535), Relieving drug (152639) and Liqi (139183). According to the first-class efficacy classification, the average frequency of the top five were tonifying deficiency (16411), promoting blood circulation and removing blood stasis (14291), regulating qi (13918), calming the mind (13203), and Wenli (12810). According to the classification of secondary efficacy, the top five frequencies were Reinforcing Qi (280733 times), reinforcing blood (150614 times), activating blood circulation and regulating menstruation (149009 times), regulating qi (139183 times) and dissipating wind-heat (1111443 times). According to the second-level classification, the average frequency of the top five were Reinforcing Qi (25521 times), reinforcing blood (25102 times), activating blood circulation and regulating menstruation (24835 times), clearing away heat and drying dampness (18118 times) and astringent intestines to stop diarrhea (15877 times).

Table 2: Efficacy classification of insomnia related Chinese medicine application frequency.

\begin{tabular}{|c|c|c|c|c|c|c|c|}
\hline & & & Frequency & & & & \\
\hline & Efficacy & & $\begin{array}{c}\text { Secondary } \\
\text { classification }\end{array}$ & & & $\begin{array}{c}\text { First class } \\
\text { classification }\end{array}$ & \\
\hline $\begin{array}{c}\text { First class } \\
\text { classification }\end{array}$ & $\begin{array}{l}\text { Secondary } \\
\text { classification }\end{array}$ & Number & Total frequency & $\begin{array}{l}\text { Average } \\
\text { frequency }\end{array}$ & Number & Total frequency & $\begin{array}{l}\text { Average } \\
\text { frequency }\end{array}$ \\
\hline \multirow{2}{*}{$\begin{array}{c}\text { Relieving } \\
\text { exterior } \\
\text { syndrome }\end{array}$} & $\begin{array}{l}\text { Dissipate } \\
\text { wind-cold }\end{array}$ & 4 & 41496 & 10374 & 12 & 152639 & 12720 \\
\hline & $\begin{array}{l}\text { Herbs used to } \\
\text { disperse } \\
\text { wind-heat }\end{array}$ & 8 & 111143 & 13893 & & & \\
\hline \multirow[t]{5}{*}{ Heat clearing } & $\begin{array}{l}\text { Clearing } \\
\text { heat-fire }\end{array}$ & 5 & 55225 & 11045 & 28 & 295220 & 10544 \\
\hline & $\begin{array}{l}\text { Heat clearing and } \\
\text { drying }\end{array}$ & 5 & 90591 & 18118 & & & \\
\hline & $\begin{array}{l}\text { Clearing away heat } \\
\text { and toxic material }\end{array}$ & 9 & 56802 & 6311 & & & \\
\hline & Blood-Cooling & 6 & 78974 & 13162 & & & \\
\hline & $\begin{array}{l}\text { Clearing deficient } \\
\text { heat }\end{array}$ & 2 & 10713 & 5357 & & & \\
\hline \multirow[t]{2}{*}{ Purgation } & Severe laxative & 2 & 27620 & 13810 & 3 & 31424 & 10475 \\
\hline & Mild laxation & 1 & 3804 & 3804 & & & \\
\hline \multirow[t]{2}{*}{$\begin{array}{l}\text { Dispelling } \\
\text { Wind and } \\
\text { dampness }\end{array}$} & $\begin{array}{l}\text { Dispel wind and cold } \\
\text { dampness }\end{array}$ & 5 & 22436 & 4487 & 9 & 42119 & 4680 \\
\hline & $\begin{array}{c}\text { Dispelling wind and } \\
\text { humid heat }\end{array}$ & 4 & 19683 & 4921 & & & \\
\hline $\begin{array}{l}\text { Resolving } \\
\text { dampness }\end{array}$ & Resolving dampness & 6 & 57687 & 9615 & 6 & 57687 & 9615 \\
\hline \multirow[t]{3}{*}{$\begin{array}{l}\text { Clearing } \\
\text { Damp and } \\
\text { Promoting } \\
\text { diuresis }\end{array}$} & $\begin{array}{l}\text { Inducing diuresis to } \\
\text { alleviate edema }\end{array}$ & 4 & 73144 & 18286 & 10 & 108731 & 10873 \\
\hline & $\begin{array}{l}\text { Inducing } \\
\text { diuresis } \\
\text { treating } \\
\text { strangurti-a }\end{array}$ & 3 & 18570 & 6190 & & & \\
\hline & $\begin{array}{l}\text { Remove Dampness } \\
\text { through diuresis }\end{array}$ & 3 & 17017 & 5672 & & & \\
\hline $\begin{array}{l}\text { Warm the } \\
\text { interior }\end{array}$ & Warm the interior & 5 & 64048 & 12810 & 5 & 64048 & 12810 \\
\hline
\end{tabular}




\begin{tabular}{|c|c|c|c|c|c|c|c|}
\hline $\begin{array}{c}\text { Regulate } \\
\text { the flow of } \\
\text { vital energy and } \\
\text { remove } \\
\text { obstructio } \\
n \text { toit }\end{array}$ & $\begin{array}{l}\text { Regulate the } \\
\text { flow of vital } \\
\text { energy and remove } \\
\text { obstruction toit }\end{array}$ & 10 & 139183 & 13918 & 10 & 139183 & 13918 \\
\hline Help digestion & Help digestion & 5 & 39157 & 7831 & 5 & 39157 & 7831 \\
\hline \multirow[t]{4}{*}{ Hemostasis } & $\begin{array}{l}\text { Cooling blood and } \\
\text { hemostasis }\end{array}$ & 2 & 9564 & 4782 & 10 & 56477 & 5648 \\
\hline & $\begin{array}{l}\text { Blood stasis and } \\
\text { hemostasis }\end{array}$ & 4 & 32145 & 8036 & & & \\
\hline & $\begin{array}{l}\text { Hemostasis with } \\
\text { astringents }\end{array}$ & 2 & 7472 & 3736 & & & \\
\hline & $\begin{array}{l}\text { Warming meridian to } \\
\text { stopv }\end{array}$ & 2 & 7296 & 3648 & & & \\
\hline \multirow[t]{4}{*}{$\begin{array}{c}\text { Promoting } \\
\text { blood } \\
\text { circulation } \\
\text { for } \\
\text { removing } \\
\text { blood } \\
\text { stasis } \\
\end{array}$} & $\begin{array}{l}\text { Promoting blood } \\
\text { Circulation to } \\
\text { arrest pain }\end{array}$ & 6 & 84277 & 14046 & 19 & 271535 & 14291 \\
\hline & $\begin{array}{l}\text { Promoting blood } \\
\text { Circulation to restore } \\
\text { menstrual flow }\end{array}$ & 6 & 149009 & 24835 & & & \\
\hline & $\begin{array}{c}\text { Blood activating and } \\
\text { healing }\end{array}$ & 3 & 11157 & 3719 & & & \\
\hline & Rupture of blood & 4 & 27092 & 6773 & & & \\
\hline \multirow[t]{3}{*}{$\begin{array}{l}\text { Resolving } \\
\text { Phlegm } \\
\text { and } \\
\text { relieving } \\
\text { cough and } \\
\text { asthma }\end{array}$} & Warming cold phlegm & 3 & 44566 & 14855 & 12 & 103677 & 8640 \\
\hline & $\begin{array}{l}\text { Clearing heat and } \\
\text { phlegm }\end{array}$ & 7 & 50644 & 7235 & & & \\
\hline & $\begin{array}{l}\text { Relieving cough and } \\
\text { asthma }\end{array}$ & 2 & 8467 & 4234 & & & \\
\hline $\begin{array}{l}\text { Relieve } \\
\text { uneasines } \\
\text { s of mind } \\
\text { and body } \\
\text { tranquilization }\end{array}$ & $\begin{array}{l}\text { Relieve } \\
\text { Uneasiness of } \\
\text { Mind and body } \\
\text { tranquilization }\end{array}$ & 8 & 105629 & 13204 & 8 & 105629 & 13204 \\
\hline \multirow[t]{2}{*}{$\begin{array}{l}\text { Calm the } \\
\text { liver to stop the } \\
\text { wind }\end{array}$} & $\begin{array}{c}\text { Calm the } \\
\text { and suppress } \\
\text { yang }\end{array}$ & 4 & 38880 & 9720 & 12 & 115391 & 9616 \\
\hline & $\begin{array}{l}\text { Resting wind and } \\
\text { spasmodic }\end{array}$ & 8 & 76511 & 9564 & & & \\
\hline $\begin{array}{l}\text { Inducing } \\
\text { resuscitation }\end{array}$ & $\begin{array}{l}\text { Inducing } \\
\text { resuscitation }\end{array}$ & 3 & 20378 & 6793 & 3 & 20378 & 6793 \\
\hline
\end{tabular}




\begin{tabular}{|c|c|c|c|c|c|c|c|}
\hline $\begin{array}{l}\text { Supplement } \\
\text { deficiency }\end{array}$ & Tonifying Qi & 11 & 280733 & 25521 & 38 & 623628 & 16411 \\
\hline & Tonifying yang & 6 & 150614 & 25102 & & & \\
\hline & Tonifying yin & 10 & 105955 & 10596 & & & \\
\hline \multirow[t]{3}{*}{$\begin{array}{c}\text { Inducing } \\
\text { astringency }\end{array}$} & $\begin{array}{l}\text { Antidarrhea with } \\
\text { astringent }\end{array}$ & 2 & 31754 & 15877 & 8 & 66420 & 8303 \\
\hline & $\begin{array}{c}\text { Treating } \\
\text { spontaneous } \\
\text { emission and } \\
\text { leukorrhagia }\end{array}$ & 5 & 29431 & 5886 & & & \\
\hline & $\begin{array}{c}\text { Strengthening } \\
\text { exterior and reducing } \\
\text { sweat }\end{array}$ & 1 & 5235 & 5235 & & & \\
\hline $\begin{array}{l}\text { Detoxicating } \\
\text { and destroying } \\
\text { parasites }\end{array}$ & $\begin{array}{c}\text { Detoxicating } \\
\text { and destroying } \\
\text { parasites }\end{array}$ & 1 & 3028 & 3028 & 1 & 3028 & 3028 \\
\hline
\end{tabular}

\section{Discussion}

Insomnia is a common clinical disease and frequently-occurring disease, but the causes of insomnia are complex, on the one hand, with its own individual psychological factors, physiological factors and genetic factors; on the other hand, with external factors such as environmental factors, physical diseases, mental illness, drug use or abstinence related. The pathophysiological mechanism is unclear, which is related to abnormalities of neurotransmitters, hormones, cytokines and circadian rhythms in the brain. Therefore, there is still a lack of truly safe and effective treatment drugs and methods. Oral sedative and hypnotic drugs such as diazepam are the most common and common treatment for insomnia [4]. However, insomniacs love and hate them because of their dependence, tolerance and addiction, residual sedation during the day and rebound after stopping the drugs. Hong Biqi and other [513] reviewed the efficacy and safety of traditional Chinese medicine in the treatment of insomnia.

In order to further understand the classification and application of Chinese medicines related to insomnia, this study used different statistical methods to analyze the first 200 kinds of Chinese medicines according to the efficacy classification of TCM. Firstly, the total frequencies of the first and second classifications of Chinese herbal medicines were counted. The results showed that there was a great correlation between the ranking results and the number of different kinds of Chinese herbal medicines. For example, according to the first-class efficacy classification, the top five frequently used tonifying deficiency, clearing away heat, promoting blood circulation and removing stasis, resolving exterior and regulating qi drugs, the number of medicines were $38,28,19,12,10$ respectively, and the frequency ranking results were consistent with the number of classified species. In order to reflect the classification of Chinese medicines related to insomnia more accurately, the average frequency of the first and second classifications were calculated respectively. The results showed that although the correlation between the number of Chinese medicines and the number of species of Chinese medicines was significantly reduced, some categories with higher frequency were found to be related to some of them, such as warming, cooling and phlegm. The frequency of Pinellia ternata is high, and the frequency of water swelling is mainly related to the frequency of Poria cocos. Although the above classification methods have some limitations, but also to a certain extent reflects the application of different categories of traditional Chinese medicine.

It needs to be noted that the statistical results of this time are based on the full-text retrieval of the relevant database, cannot analyze the original text of the relevant literature, so inevitably there will be statistical incompleteness, and there will also be a certain drug is not a treatment for insomnia, but due to appear in the literature was statistical phenomenon. Therefore, the results of this study only reflect to some extent the objective situation of traditional Chinese medicine in treating insomnia. In summary, quantitative analysis of information found that the frequency of insomnia-related traditional Chinese medicine was higher than that of licorice, Angelica sinensis, Atractylodes macrocephala, Salvia miltiorrhiza, Bupleurum root, paeony root, Astragalus membranaceus, Poria cocos, Pinellia ternate and Codonopsis pilosula. According to the efficacy classification of TCM, the most frequently used drugs were tonic, heat-clearing, blood-activating and stasis-removing, Qi-Regulating and tranquilizing drugs. The results of this study reflect to some extent the current clinical application of insomnia-related Chinese medicine, which can be used as a reference for the future use of Chinese medicine in the treatment of insomnia.

\section{Acknowledgement}

The study was supported by the Natural Science Foundation of the Fujian Province(2016J01563), the Youth scientific research project of fujian health and family planning commission(2016-1-80).

\section{References}

1. (2017) Chinese Sleep Research Society (CSRS) Guidelines for diagnosis and treatment of insomnia in China. Chinese Medical Journal 97(24): 1844-1856. 
2. Gao Xuemin (2008) Chinese Materia Medica[M]. Chinese Medicine Press, Beijing, China, p. 51-523.

3. Sun Yanna, Qiao Tie, Zhang Lide (2017) Effect and Mechanism Comment of Traditional Chinese Medicine on Insomnia. Chinese Archives of Traditional Chinese Medicine 35(7): 1873-1875.

4. Song Chuan fu, Li Jiangyong, Cheng Wanliang (2009) Analysis the First Use of Drugs in Outpatients with Insomnia. China Journal of Health Psychology 17(2): 253-255.

5. Hong Biqi, Zhong Lilun, Peng Yinjun (2017) Research summary of insomnia treated by Chinese Medicine. Chinese Journal of Ethnomedicine and Ethnopharmacy 26(7): 69-72.

6. Zhou Zhongying (Eds.). (2007) Internal medicine of traditional Chinese Medicine[M]. (2 ${ }^{\text {nd }}$ Edn.). Chinese Medicine Press, Beijing, China, pp.146152.

7. Si Fuchun (2007) Analysis on Syndromes of Insomnia and TCM Prescriptions. World Journal of Integrated Traditional and Western Medicine 2(9): 520-523.

8. Wu Xiangmei, Huang Shenrong, Guan Yiting (2012) Clinical observation of Xuefu Zhuyu Decoction Combined with stellate ganglion block in the treatment of insomnia with depression. CJTCM 24(6): 508-509.

\section{ISSN: 2574-1241}

DOI: 10.26717/BJSTR.2018.10.002016

Cheng Han Wu. Biomed J Sci \& Tech Res

cC (P) This work is licensed under Creative

BY Commons Attribution 4.0 License

Submission Link: https://biomedres.us/submit-manuscript.php
9. Cui Jiefeng, Yang Wei, Xie Yanming (2014) Real-World analysis of concurrent diseases and medicine use among patients with insomnia. Chin J Chin Mat Med 39(18): 3519-3526.

10. Ding Haiqun, Pei Rong (2015) 100 cases of insomnia treated by Xuefu Zhuyu Decoction. China's Naturopathy 6: 49-50.

11. Jiang Xiao, Feng Hui, Ding Yuanqing (2016) Analysis of Ding Yuanqing's Medication Rule in Prescriptions for Insomnia of Yin Deficiency and Blood Stasis. Liaoning Journal of Traditional Chinese Medicine 42(2): 234-238.

12. Li Guochen, Zhang Shengjun, Wang Sen (2017) Analysis of the Basic Syndromes and Prescription of Insomnia. Clinical journal of traditional chinese medicine 29(11): 1820-1822.

13. Wang Ning, Ma Hua, Ma Tiancheng (2018) Modified Suanzaoren Decoction in the Treatment of Insomnia:a Meta-analysis. Chinese Journal of Integrative Medicine on Cardio-/Cerebrovascular Disease 16(1): 32-36

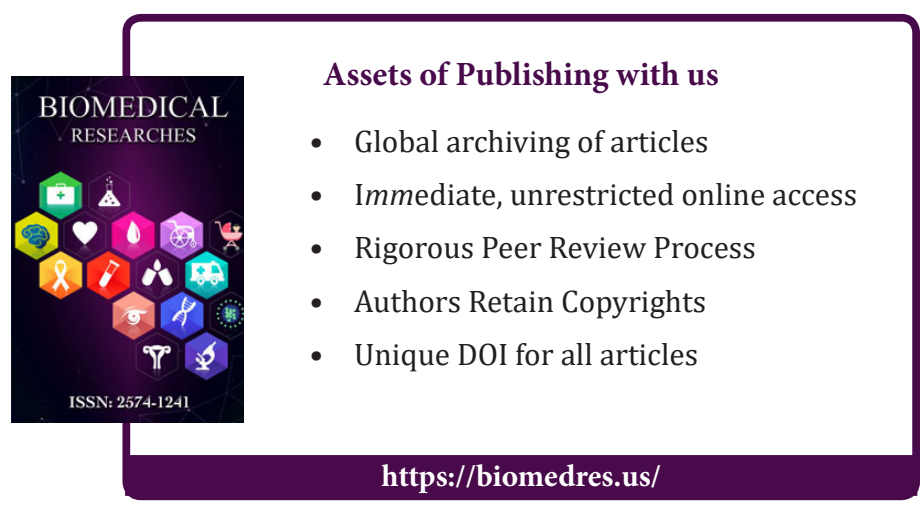

